\title{
Modification of Seawater Scrubber System into Freshwater of Inert Gas System on the Crude Oil Tanker 85,000 DWT
}

\author{
Nurhadi Siswantoro ${ }^{1}$, Hari Prastowo ${ }^{2}$, Faris Zulfar Rosyadi ${ }^{3}$ \\ (Received: 01 August 2019 / Revised: 10 March 2020 / Accepted: 21 June 2020)
}

\begin{abstract}
Each ship is carrying a hydrocarbon must be equipped with an inert gas system. On tankers, the function of inert gas is to prevent fires or explosions caused by oxygen levels contained in cargo tanks. Inert gas is produced by cleaning the exhaust gas boiler using a seawater scrubber system. However, seawater has corrosive properties that cause the use of the material in scrubber system components to be resistant to corrosion. Therefore, through this research, a modification of the seawater scrubber system was made into a freshwater scrubber system. The advantages of a freshwater scrubber system include a low corrosive level that causes the use of inexpensive materials. Modification of seawater scrubber systems into freshwater causes additional components to be made, including adding $\mathrm{NaOH}$ tank, expansion tank of freshwater, seawater pumps, freshwater pumps, $\mathrm{NaOH}$ pumps, heat exchanger, and wash water treatment unit. Economic calculations are carried out to determine the installation costs and operational costs needed from this modification. Based on the technical and economic analysis, modification of the seawater scrubber system into a freshwater inert gas system of Crude Oil Tanker 85,000 DWT can be done with an estimated installation cost of 1.5 Bill. Rupiahs.
\end{abstract}

Keywords — freshwater, inert gas, modification, scrubber, seawater.

\section{INTRODUCTION}

E ach ship carrying a hydrocarbon must be equipped with an inert gas system. By its definition, the inert gas is a gas that does not experience chemical reactions [1]. On tankers, the function of the inert gas system is to prevent fires and explosions caused by the oxygen content contained in the cargo tank [2]. In generating fire, three main factors are needed, namely fuel, heat, and oxygen, with a level of at least $11 \%$ of the total air [3]. boiler. On this ship, cleaning the exhaust gas is carried out by using seawater as the main medium for inert gas cleaning in the scrubber system [5]. For the use of seawater media, seawater is taken using a seawater pump that is directly distributed into the scrubber to be used as an exhaust gas cleaning medium. After being used, the seawater is directly flowed out of the ship through an overboard [6].

Using seawater as a gas inert cleaning medium has several advantages, which are easy to obtain and have natural alkalinity. However, seawater has corrosive properties that cause the use of the material in the

TABLE 1.

ClASSIFICATION OF $\mathrm{O}_{2}$ IN CARGO TANK

\begin{tabular}{cc}
\hline $\mathrm{O}_{2}$ Percentage & Status \\
\hline $11 \%$ & Max. Oxygen Level \\
$8 \%$ & Max. Oxygen Level Allowed \\
$5 \%$ & Satisfactory Oxygen Level \\
$<3 \%$ & Best Oxygen Level \\
\hline
\end{tabular}

Inert gas can be produced in several ways, one of which is to use flue gas or exhaust gas from the boiler [4]. The exhaust gas boiler can be used as an inert gas because the exhaust gas boiler has a low oxygen level.

On Crude Oil Tanker, 85,000 DWT utilizing exhaust gas from the boiler to be used as the inert gas. The inert gas from the exhaust gas boiler cannot be directly used into the cargo tank but must go through a cleaning process from the impurities in the form of solid particles which are carried away from the combustion of the

\footnotetext{
${ }^{2}$ Nurhadi Siswantoro, Departement of Marine Engineering, Institut Teknologi Sepuluh Nopember, Surabaya, 60111, Indonesia. E-mail: nurhadi@ne.its.ac.id

${ }^{1}$ Hari Prastowo, Department of Marine Engineering, Institut Teknologi Sepeluh Nopember, Surabaya, 60111, Indonesia, E-mail: h-prastowo@its.ac.id

${ }^{3}$ Faris Zulfar Rosyadi, Departement of Marine Engineering, Institut Teknologi Sepuluh Nopember, Surabaya, 60111, Indonesia. E-mail: faris.zulfar@gmail.com
}

scrubber system components of the inert gas system to be resistant to corrosion. Corrosive properties of seawater also cause maintenance of components to be carried out more often so that the components are in good condition. Thus, the use of seawater to clean inert gas is ineffective because the cost of components is expensive, and the treatment must be more frequent [7].

Therefore, through this research, a scrubber system modification of the Crude Oil Tanker 85,000 DWT that uses seawater as an exhaust gas cleaning medium into freshwater. The main reason for using freshwater is because the properties of freshwater are not corrosive, allowing the use of materials that is not as good as when using the seawater system. Due to the properties of freshwater that are not corrosive, components treatment is not carried out too often. This research will provide an overview related to the modification of the scrubber system in the inert gas system of tankers from the use of seawater into freshwater. 

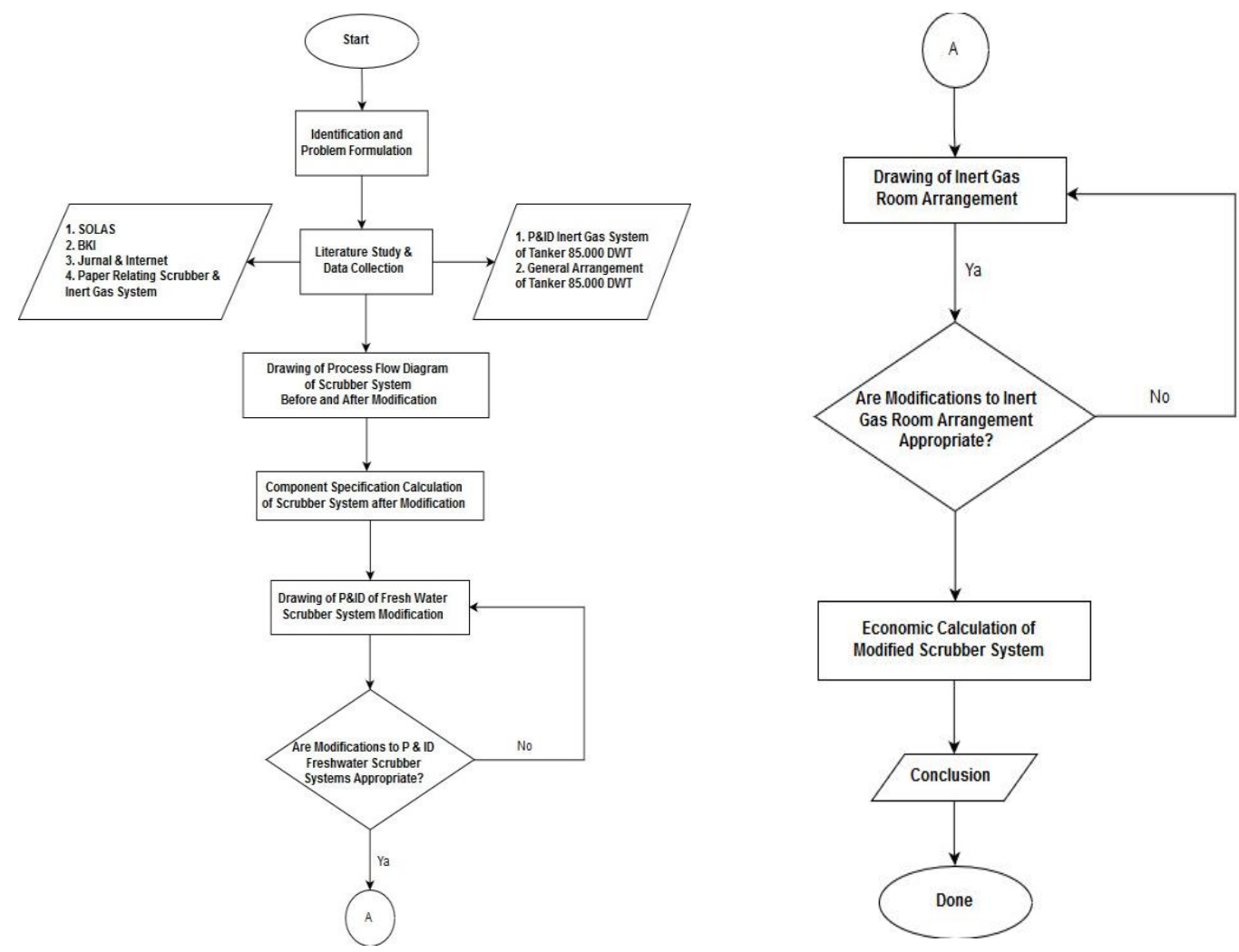

Figure 1. Research flow diagram.

\section{METHOD}

Research Method is the basic framework of research that covers all activities to solve a problem with the stages that have been prepared, such as problem formulation, literature review, design, calculation, validation, and results. The results of a study are expected to provide concrete solutions. The research flow diagram can be seen in Figure 1.

1) Identification and State Problem

In this research, the first step to be carried out is the identification and formulation of the problem. The problem that is taken is in the inert gas system of the Crude Oil Tanker 85,000 DWT. Due to the ineffective use of the seawater scrubber system due to the corrosive properties it possesses, modifications are made into freshwater systems that have lower corrosion rates.

2) Literature Study and Collecting Data

A literature study is a next step to obtain information that supports the completion of this thesis. The information is in the form of theory, work methods, regulations, and standards. Literature studies can be obtained by reading books, journals, papers, regulations, and standards related to the discussion in this thesis.

In addition to literature studies, data collection is also used to support data processing as initial input. The following are the data needed in this thesis, including:

1) Piping and Instrumentation Diagram of Crude Oil Tanker 85.000 DWT.

2) General Arrangement of Crude Oil Tanker 85.000 DWT
3) Drawing of Process Flow Diagram

Next is the drawing of the Process Flow Diagram of the scrubber system of the inert gas system. PFD drawings are carried out for existing systems and for modified systems. PFD drawings are done to find out the processes that are passed through the scrubber system of the inert gas system.

4) Calculation of Required Components

After that, the calculation is done to find out the needs of the components in the modified scrubber system. The calculation of component requirements refers to the system that has been installed, so it does not recalculate from scratch but uses some components on the old system to then add components to the new system. So from the calculation of component requirements, components can be determined with specifications suitable for the new scrubber system. The calculation is done in detail for the system currently in use and the system modification.

5) Drawing of Piping \& Instrumentation Diagram Modification

After obtaining Piping \& Instrumentation Diagram data from the Inert Gas System that has been installed on the Crude Oil Tanker 85,000 DWT, it can be seen the processes being passed to produce inert gas, which is then supplied to the cargo tank. Furthermore, modifications are made to the new system components based on the requirements specified in the previous stage. So that with the new component, the appropriate $\mathrm{P}$ $\&$ ID can be drawn. 
6) Drawing of Inert Gas Room Arrangement Modification

The next process is modification of the inert gas room arrangement. After knowing the specifications of the components of the new system, modifications are also made to the inert gas room. By using General Arrangement data on ships, modification of additions and changes in components can be made. Additions and changes to these components are adjusted to the available inert gas rooms.

\section{7) Economic Calculation}

Economic calculation is a cost calculation for modifications made. Economic calculations carried out in this study are limited to asset investment costs and operational costs needed for modified systems. The value taken in determining equipment prices is based on domestic shipyard data and online platforms for ship equipment.

\section{8) Conclusion and Suggestion}

The last stage in this research is the conclusions and suggestions obtained by completing all stages of the flow diagram in Figure 1. Then, suggestions can be given, and this research can be used as the basis for further research related to scrubber system modification of the inert gas system or other research.

\section{RESULT AND DISCUSSION}

\section{A. Scrubber System Analysis}

1) Seawater Scrubber System Analysis

In the Crude Oil Tanker 85,000 DWT using a seawater scrubber system in the inert gas system. The use of seawater is to clean flue gas boilers from substances containing acids such as $\mathrm{SO}_{2}$ and $\mathrm{NO}_{\mathrm{x}}$, as well as to clean from dust and ash, which are also carried by the exhaust gas. The cleaning process through which exhaust gas is passed is by flowing seawater from the top of the scrubber, with exhaust gas flowing from the bottom of the scrubber.

The gas produced from the gas cleaning process in the scrubber is a clean gas, which is free of substances that have acidic contents and impurities. For flue gas cleaning media, namely seawater, then it will be immediately discarded back into the sea without a cleaning process. The use of seawater as a flue gas cleaning media has advantages and disadvantages. Advantages of using seawater as the cleaning medium are :

- Easy to get

- Amount of Seawater is Unlimited

- Seawater has natural alkalinity

- The installation system is more simple.

regardless of its advantages, the seawater system has disadvantages, including :

- Corrosive

- The system uses more expensive materials

- Maintenance of components must be more frequent

- The ability to clean the exhaust gas depends on the condition of the waters
2) Freshwater Scrubber System Analysis

Freshwater scrubber systems are also called "closed type systems." As the name implies, a freshwater scrubber system allows the boiler exhaust gas cleaning media in the gas inert system scrubber to be recirculated and reused to clean the exhaust gas. However, the advantages of using freshwater media are not from the closed system, but from the nature of the freshwater media that are not corrosive so that the lifetime of equipment and maintenance can be made longer. The use of freshwater as a waste gas cleaning media has several advantages, including :

- Freshwater has the corrosive level

- Absence of water and waste disposal into the sea

- The system can use cheaper materials

- Maintenance of Components are less frequent

- The ability to clean the exhaust gas does not depend on the condition of the water

regardless of its advantages, the seawater system has disadvantages, including :

- The system carries additional freshwater and additional $\mathrm{NaOH}$

- The installation of the system is more complicated

- The new system needs additional components

- Maintenance must be done for more components

\section{B. Drawing of Process Flow Diagram}

In designing the scrubber system, the first is to describe Process Flow Diagrams (PFD). PFD is done to find out the processes that are passed in a system, wherein this system is a scrubber system in the inert gas system [8]. There are two systems of drawing, namely a seawater scrubber system, and a freshwater scrubber system. PFD seawater scrubber system can be seen in Figure 2.

In seawater systems, seawater, which is the main media for boiler exhaust gas, is taken from the sea [9]. The seawater taken will be temporarily stored in the sea chest box. The determination of the size of the sea chest box itself is based on seawater requirements on the ship. When a scrubbing process occurs, seawater will be flowed by utilizing a seawater pump. The filtration process occurs before seawater flows to the pump, namely through a filter. The use of filters is to filter out impurities that have the potential to clog the pump. Seawater goes straight to the scrubber tank to clean the exhaust gas from the boiler. The cleaning process is done by spraying it through the nozzle inside the tank. The function of using this nozzle is that sprayed seawater can spread to all parts of the scrubber tank so that it can clean the exhaust gas thoroughly. But in addition to being used by spraying, seawater is also used by way of being accommodated in a "pool" or what is called a seal. This seawater pool is inside the scrubber tank. This pool is the place where the exhaust gas comes out of the boiler exhaust system to be cleaned.

The media used to clean the exhaust gas, whether flowing from the top of the scrubber or in the seal or 


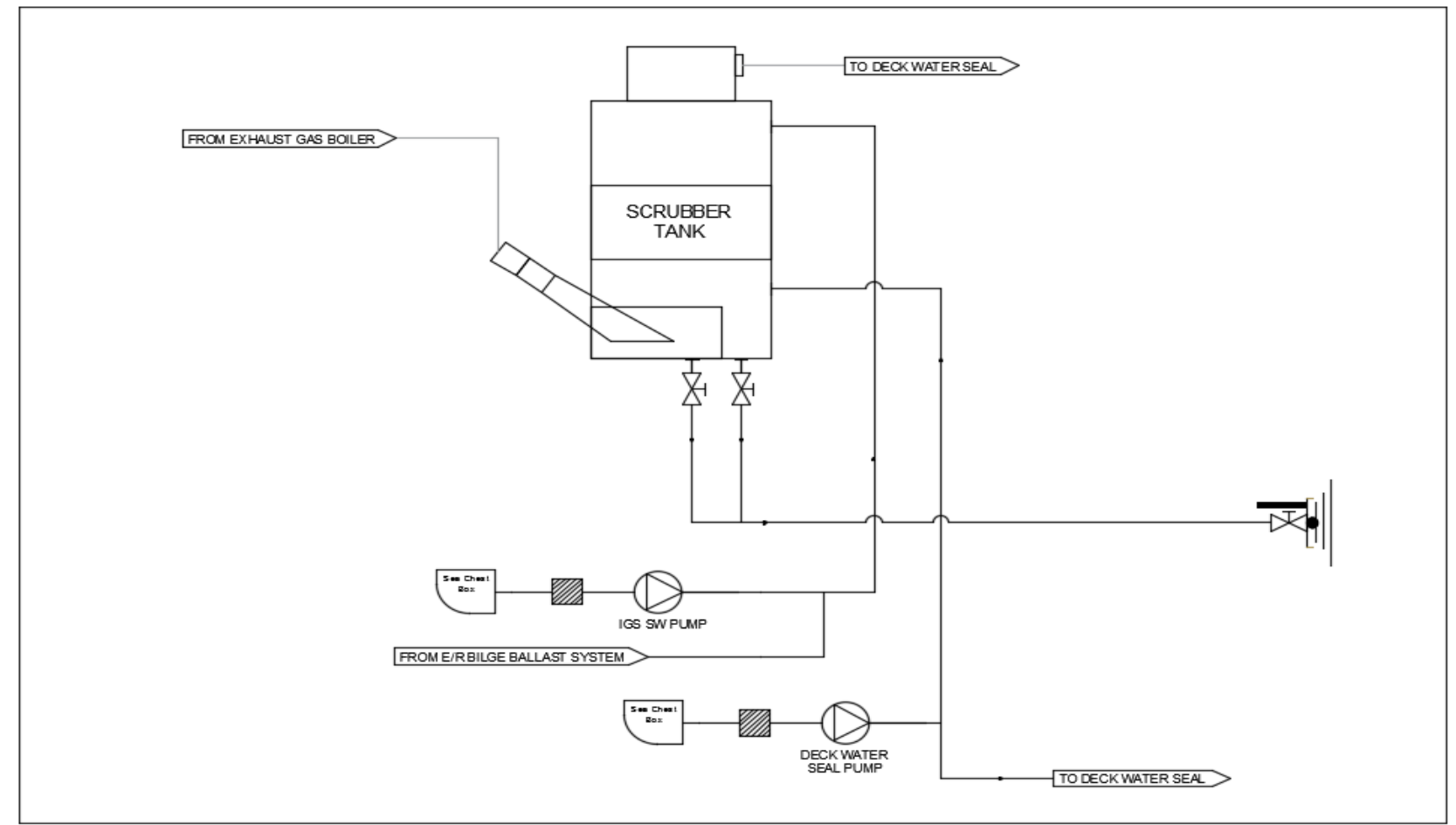

Figure. 2. Process flow diagram of seawater scrubber system.

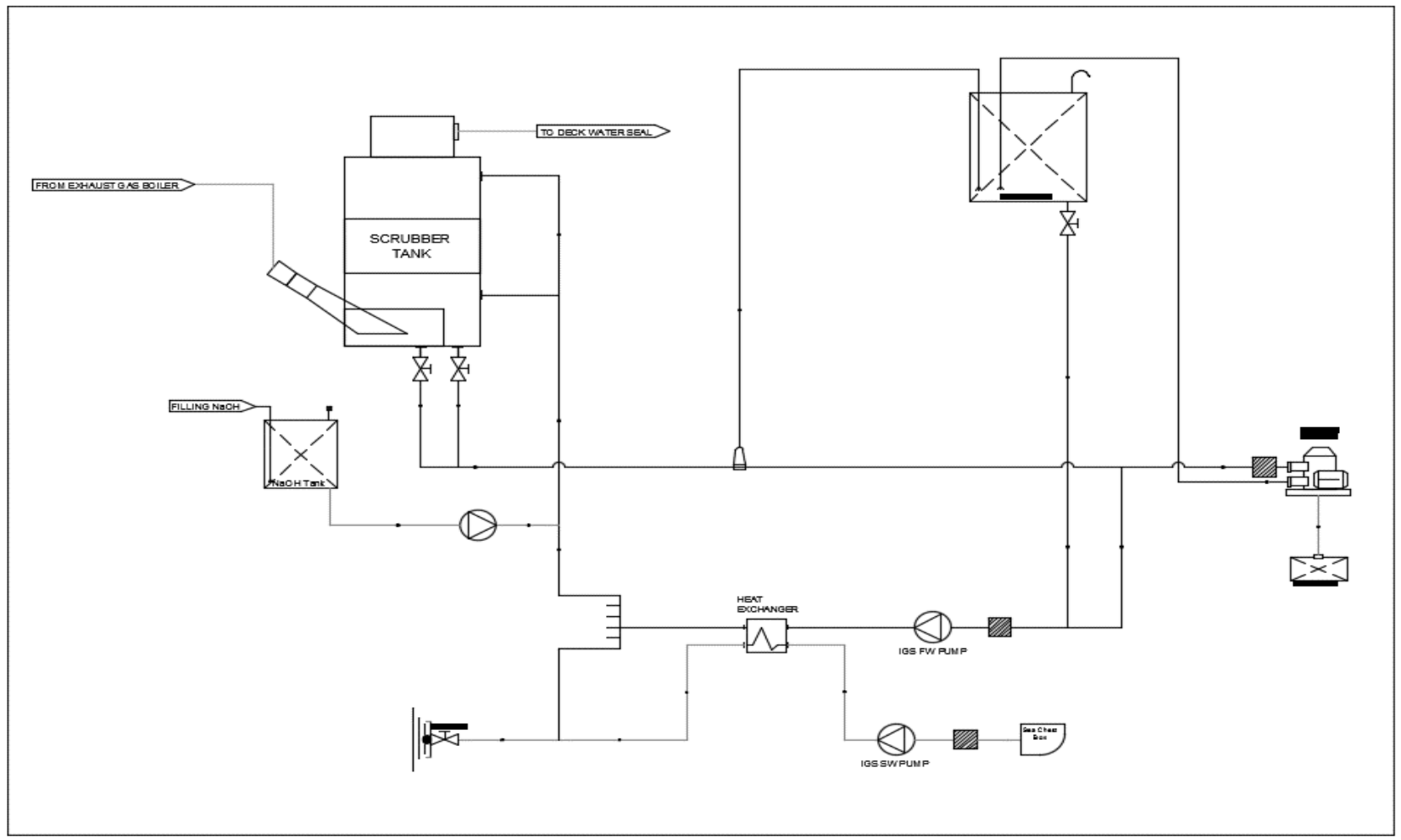

Figure. 3. Process flow diagram of freshwater scrubber system.

pond, is seawater. However, the use of pumps to drain into these two parts is different. Where for seawater flowing at the top of the scrubber comes from the pump inert gas system or called IGS Seawater Pump. If the IGS SW Pump cannot function, there is another source, which comes from the Engine Room Bilge Ballast System. Both of these systems both supply seawater and then flow from the top of the scrubber by spraying. Whereas for seawater, which is in the form of a "pool" or seals originating from the Deck Water Seal Pump, which besides being used for scrubber tanks, is also used for the Deck Water Seal. Seawater that has been used to clean the exhaust gas will be flowed into the overboard to be dumped back into the sea. The process of removing seawater does not use a pump, but by utilizing the difference in height that causes seawater to flow by itself.

In freshwater scrubber systems, freshwater is carried by the ship when sailing. The freshwater will be stored in the piping system, and then using the pump will give a boost to the top of the scrubber. When freshwater has flowed into the scrubber, freshwater is injected with a strong base solution to neutralize the acid content carried in the exhaust gas. The basic solution commonly used is Sodium Hydroxide $(\mathrm{NaOH})$. Because freshwater does not have natural alkalinity, the addition of alkaline 
solutions is required to prevent acid content from dissolving and polluting the environment. Like a seawater scrubber system, a freshwater scrubber system cleanses the boiler exhaust gas by spraying it through a nozzle from the top of the scrubber, by having a "pool" or called a seal on the bottom side of the scrubber where the exhaust gas comes out. Freshwater that has been used to clean the exhaust gas is then cleaned using a wash water treatment to be separated between water and sludge. The sludge is then released to the sludge tank to be removed, while the water will be circulated again to clean the exhaust gas. Schemes in freshwater systems can be seen in Figure 3.

In the freshwater scrubber system has several additional components that are not owned by the seawater scrubber system. Some of these components include the Chemical Addition, Expansion Tank, Wash Water Treatment, and Heat Exchanger.

\section{Scrubber System Modification Calculation}

1) Composition of Exhaust Gas

The first step in modifying the scrubber system is to
Nitrogen Dioxide $\left(\mathrm{NO}_{2}\right)$

$$
\begin{aligned}
\mathrm{V} \mathrm{NO}_{2} & =11.250 \times 0,04 \% \times 10 \% \\
& =0,45 \mathrm{~m} 3 / \mathrm{h} \\
\mathrm{\rho} \mathrm{NO}_{2} & =1450 \mathrm{~kg} / \mathrm{m} 3 \\
\mathrm{~m} \mathrm{NO}_{2} & =0,45 \times 1450 \\
& =652,5 \mathrm{~kg} / \mathrm{h}
\end{aligned}
$$

\section{2) Calculation of Added $\mathrm{NaOH}$}

After knowing the level of the substance to be cleaned by the scrubber system, then calculating the amount of addition of $\mathrm{NaOH}$ base needed, the process of adding base is done due to differences in the properties possessed of freshwater and seawater. In seawater, it has natural alkalinity, so it can neutralize the acid content carried by the exhaust gas. While alkalinity is not possessed by freshwater, it is necessary to add bases to neutralize the acid carried in the exhaust gas [11].

The first step in determining the addition of $\mathrm{NaOH}$ base is to calculate the reaction that occurs with the acid compound to be cleaned. Where in this process, acids that react with bases are $\mathrm{SO}_{2}, \mathrm{NO}$, and $\mathrm{NO}_{2}$.

TABLE 2.

Substance LeVEl of EXHAUST Gas BoILER

\begin{tabular}{cc}
\hline Substance & Content $\%$ \\
\hline $\mathrm{N}_{2}$ & $77 \%$ by Volume \\
$\mathrm{CO}_{2}$ & $13 \%$ by Volume \\
$\mathrm{H}_{2} \mathrm{O}$ & $5 \%$ by Volume \\
$\mathrm{O}_{2}$ & $4 \%$ by Volume \\
$\mathrm{SO}_{2}$ & $0,3 \%$ by Volume \\
$\mathrm{NO}_{\mathrm{x}}$ & $0,04 \%$ by Volume \\
$\mathrm{CO}$ & $0,1 \%$ by Volume \\
Dirt and Ashes & $\pm 150 \mathrm{mg} / \mathrm{m}^{3}$ \\
\hline
\end{tabular}

calculate the level or composition of the substance in the exhaust gas to be cleaned. In the scrubber system, there are three substances to be cleaned, namely $\mathrm{NO}, \mathrm{NO}_{2}$, and $\mathrm{SO}_{2}$. Cleansing these three substances is because the substance is acidic. So that if left unchecked, it has the potential to damage the environment, one of which is to create acid rain. The levels of substances in boiler exhaust gases are shown in Table 2 [10].

From Table 2., you can see the levels of substances carried in the boiler exhaust gas. Of these substances, there are three substances that will be cleaned, namely $\mathrm{NO}_{x}$, which consists of $\mathrm{NO}$ and $\mathrm{NO}_{2}$, with levels of $0.04 \%$ and $\mathrm{SO}_{2}$ with a concentration of $0.3 \%$. The levels of these substances are still in units of percent. Next, calculate the levels to be the actual size. The reference used to calculate the level of the substance is the exhaust rate as a whole.

$$
\begin{aligned}
& \text { Sulphur Dioxide }\left(\mathrm{SO}_{2}\right) \\
& \qquad \begin{aligned}
\mathrm{V} \mathrm{SO}_{2} & =11.250 \times 0,3 \% \\
& =33,75 \mathrm{~m}^{3} / \mathrm{h} \\
\mathrm{\rho} \mathrm{SO}_{2} & =2,63 \mathrm{~kg} / \mathrm{m}^{3} \\
\mathrm{~m} \mathrm{SO}_{2} & =33,75 \times 2,63 \\
& =88,76 \mathrm{~kg} / \mathrm{h}
\end{aligned}
\end{aligned}
$$

Nitrogen Monoxide (NO)

$\begin{array}{ll}\text { V NO } & =11.250 \times 0,04 \% \times 90 \% \\ & =4,05 \mathrm{~m} 3 / \mathrm{h} \\ \rho \mathrm{NO} & =1,34 \mathrm{~kg} / \mathrm{m} 3 \\ \mathrm{~m} \mathrm{NO} & =4,05 \times 1,34 \\ & =5,427 \mathrm{~kg} / \mathrm{h}\end{array}$

- $\mathrm{NaOH}+\mathrm{SO}_{2}$

The amount of $\mathrm{NaOH} \quad=110,96 \mathrm{~kg} / \mathrm{h}$

Remaining content $\quad=22,2 \mathrm{~kg} / \mathrm{h}$

- $\mathrm{NaOH}+\mathrm{NO}$

The amount of $\mathrm{NaOH}=3,618 \mathrm{~kg} / \mathrm{h}$

- $\mathrm{NaOH}+\mathrm{NO}_{2}$

The amount of $\mathrm{NaOH} \quad=547,4 \mathrm{~kg} / \mathrm{h}$

Total addition of $\mathrm{NaOH}$ for one scrubbing process

$=110,96 \mathrm{~kg} / \mathrm{h}-22,2 \mathrm{~kg} / \mathrm{h}+3,618 \mathrm{~kg} / \mathrm{h}+547,4 \mathrm{~kg} / \mathrm{h}$

$=639,78 \mathrm{~kg} / \mathrm{h}$

Density of $\mathrm{NaOH} \quad=2130 \mathrm{~kg} / \mathrm{m}^{3}$

Flow Rate of $\mathrm{NaOH} \quad=0,3 \mathrm{~m}^{3} / \mathrm{hr}$

3) Wash Water Treatment

Wash water treatment is a process of water treatment to separate water and dirt from the exhaust gas cleaning process. The treatment of scrubbing or wash water is using a device from Wartsila. The steps for cleaning wash water are as follows [12]:

- Using dissolved air, the oil contained within the wash water is floated to the surface, where it is skimmed off.

- Suspended particulate matter is removed using coagulation and flocculation processes. Coagulants are used to neutralize negative charges, causing particles to repel each other so 
that they are unable to agglomerate. Flocculent then combines the neutrally charged particles into larger masses.

- Dissolved air flotation is again used to separate and remove particles from the wash water.

- Before discharge, the wash water is finally subjected to active carbon filtration. The carbon has a very high surface area because of its micro-porosity and is effective at the removal of organic compounds, including PAHs, by adsorption.

The treated water quality has characteristics that meet the IMO regulations as follows [13]:

- The turbidity level is less than $25 \mathrm{FNU}$

- PAH do not exceed $1226 \mu \mathrm{g} / 1$

- $\mathrm{pH}$ levels exceed the value of 6.5

- Nitrate levels contained less than $1350 \mathrm{mg} / \mathrm{l}$

4) Cooling Process

Heat transfer occurs during the scrubbing process. There are two times the heat transfer process occurs. First is the process when cleaning the exhaust gas in the scrubber. The heat from the exhaust gas will be transferred to the freshwater. The second process is heat transfer that occurs when the freshwater after the scrubbing process being cooled down by using seawater [14].

In process 1, what you want to know is the temperature of freshwater after going through the cleaning process in the scrubber. By cleaning the exhaust gas using freshwater, the temperature of freshwater will increase. Then the heat transfer calculation is carried out as follows:

Known as follows:

- The gas temperature entering the scrubber $=300{ }^{\circ} \mathrm{C}=573.15 \mathrm{~K}$

- The gas temperature of the exit the scrubber $=50^{\circ} \mathrm{C}=323.15 \mathrm{~K}$

- Scrubber intake water temperature $=35^{\circ} \mathrm{C}=308.15 \mathrm{~K}$

- Water Flow Rate $=205 \mathrm{~m}^{3} / \mathrm{h}$

Where :

- $\rho$ of Water $\quad=997 \mathrm{~kg} / \mathrm{m}^{3}$

- mass of Water $\quad=204,385 \mathrm{~kg} / \mathrm{h}$

- cp of Water $\quad=4.18 \mathrm{~kJ} / \mathrm{kgK}$

- $\mathrm{mx} \mathrm{cp} \mathrm{Gas} \quad=43538.85 \mathrm{~kg} / \mathrm{h}$

Calculation :

$$
\begin{gathered}
Q 1=Q 2 \\
m \times c x \Delta T=m \times c x \Delta T \\
204,385 \times 4.18 x(T 2-308,15)=43538.85 \times(573,15-323,15) \\
T 2-308,15=\frac{10,884,712.5}{204,385 \times 4.18} \\
T 2-308,15=12.74 \\
T 2=320.89 \mathrm{~K} \\
\mathbf{T 2}=\mathbf{4 7 . 7 4}^{\circ} \mathrm{C}
\end{gathered}
$$

Known:

- Water Inlet Temperature

$$
=47.74{ }^{\circ} \mathrm{C} \quad=320.89 \mathrm{~K}
$$

- Water Outlet Temperature

$$
=35^{\circ} \mathrm{C} \quad=308.15 \mathrm{~K}
$$

- Mass of Water

$$
=35^{\circ} \mathrm{C} \quad=308.15 \mathrm{~K}
$$

- $\quad \mathrm{Cp}$ of Water $=4.18 \mathrm{~kJ} / \mathrm{kgK}$

Then, the heat released is as follows:

$$
\begin{aligned}
& Q=m \times c \times \Delta T \\
& Q=204,385 \times 4.18 \times(320.89-308.15) \\
& Q=10,884,155.28 \mathrm{~kJ} / \mathrm{h} \\
& Q=3023.38 \mathrm{~kW}=4054.42 \mathrm{HP}
\end{aligned}
$$

The calculation on process 2 is to find out the amount of heat released by the wash water so that the water is ready to be reused in the next cycle. After knowing the amount of heat released, then it determines the need for seawater as a cooling medium.

\section{Cooling Water Needs}

Known :

- The water inlet temperature $=30^{\circ} \mathrm{C}=303.15 \mathrm{~K}$

- The water outlet temperature $=40^{\circ} \mathrm{C}=313.15 \mathrm{~K}$

- $\quad$ Heat $(\mathrm{Q})$ $=10,884,155.28 \mathrm{~kJ} / \mathrm{h}$

- $\quad$ p of Seawater $=4,012 \mathrm{~kJ} / \mathrm{kgK}$

Calculation:

$$
\begin{aligned}
m & =\frac{Q}{c p \times \Delta T} \\
m & =\frac{10,884,155.28}{4.012 \times(313.15-303.15)} \\
m & =271,290 \mathrm{~kg} / \mathrm{h}
\end{aligned}
$$

$\begin{array}{ll}\text { Density of Seawater } & =1025 \mathrm{~kg} / \mathrm{m}^{3} \\ \text { Flow Rate of Seawater } & =264.67 \mathrm{~m}^{3} / \mathrm{hr}\end{array}$

5) Tank Calculation

By modifying seawater, there are at least three tanks that need to be calculated to determine the volume requirements of the tank. The tank that needs to know the volume are the expansion tank, $\mathrm{NaOH}$ tank, and sludge tank.

- $\quad$ Freshwater Expansion Tank

Freshwater volume in the system $=2,67 \mathrm{~m}^{3}$

Estimated Tank Size $\quad=3-4 \%$ of Total Vol.

Expansion Tank Requirement $\quad=0,11 \mathrm{~m}^{3}$

- $\mathrm{NaOH}$ Tank

Flow Rate

Estimated Tank Size

$=0,3 \mathrm{~m}^{3} / \mathrm{h}$

$=$ Duration of Inert

Gas Operation

$=23 \mathrm{hr}$

$=7 \mathrm{~m}^{3}$ 
- $\quad$ Sludge Tank

Amount Sludge Estimation

Boiler Power Output

Amount of Sludge

Density of ashes

Sludge Tank Volume
$=0,4 \mathrm{gr} / \mathrm{MWh}$ of Scrubbed engine

$=12,7 \mathrm{MW}(2$ Sets)

$=233,68 \mathrm{~kg}$

$=610 \mathrm{~kg} / \mathrm{m}^{3}$

$=0,38 \mathrm{~m}^{3}$

6) Pipe Calculation

Pipe calculations are carried out to determine the size and dimensions of the pipes that are in the scrubber system after being modified. At least there are three types of pipes that need to be calculated, including $\mathrm{NaOH}$ pipes, freshwater pipes, and seawater cooling pipes [15].

$\mathrm{NaOH}$ Pipe Calculation

$\begin{array}{ll}\text { Flow Rate } & =0,3 \mathrm{~m}^{3} / \mathrm{h} \\ \text { Pipe Diameter } & =10,5 \mathrm{~mm} \\ \text { Thickness Min. } & =1,0 \mathrm{~mm}\end{array}$

Freshwater Pipe Calculation

Before Scrubber Tank

Flow Rate

Pipe Diameter

Thickness Min.

$$
\begin{aligned}
& =205 \mathrm{~m}^{3} / \mathrm{h} \\
& =202,6 \mathrm{~mm} \\
& =5,4 \mathrm{~mm}
\end{aligned}
$$

After Scrubber Tank

Flow Rate

Pipe Diameter

$=205 \mathrm{~m}^{3} / \mathrm{h}$

$=304,2 \mathrm{~mm}$

Thickness Min.

$=6,3 \mathrm{~mm}$

Expansion Tank

Flow Rate

Pipe Diameter

Thickness Min.

$=5 \mathrm{~m}^{3} / \mathrm{h}$

$=42,2 \mathrm{~mm}$

$=2 \mathrm{~mm}$

Seawater Pipe Calculation

Flow Rate

$=265 \mathrm{~m}^{3} / \mathrm{h}$

Pipe Diameter

$=126 \mathrm{~mm}$

Thickness Min.

$=2,3 \mathrm{~mm}$

\section{7) Pump Calculation}

Pump calculation is carried out to determine the need for a pump to drain the fluid inside a freshwater scrubber system. There are three types of fluid, namely $\mathrm{NaOH}$, freshwater, and seawater. These three types of fluid must know the head requirements and their flow capacity to then be able to choose the appropriate pump.

\section{$\mathrm{NaOH}$ Pump Required}

\section{Head}

Capacity

$$
\begin{aligned}
& =3,02 \mathrm{~m} \\
& =0,3 \mathrm{~m}^{3} / \mathrm{h}
\end{aligned}
$$

Seawater Pump Required

Head

Capacity

$$
=68,2 \mathrm{~m}
$$$$
=265 \mathrm{~m}^{3} / \mathrm{h}
$$

Freshwater Pump Required

Head

Capacity

$$
=36,81 \mathrm{~m}
$$$$
=205 \mathrm{~m}^{3} / \mathrm{h}
$$

\section{Component Selection}

After the calculations related to the modification process in the freshwater scrubber system are carried out,

\begin{tabular}{|c|c|}
\hline Brand & $=$ Evergush \\
\hline Type & $=\mathrm{XA} 80 / 20 \mathrm{~A}$ \\
\hline Capacity & $=216 \mathrm{~m}^{3} / \mathrm{h}$ \\
\hline Head & $=44,5 \mathrm{~m}$ \\
\hline Power & $=37 \mathrm{~kW}$ \\
\hline
\end{tabular}
then the available components can be selected according to the calculation requirements. The selected components, including pumps, heat exchangers, and wash water treatment.

$\begin{array}{ll}\mathrm{NaOH} \text { Pump } & =\text { Forte Pumps } \\ \text { Brand } & =\mathrm{T}-\mathrm{CL} 7572 \\ \text { Type } & =54 \mathrm{~m}^{3} / \mathrm{h} \\ \text { Capacity } & =31 \mathrm{~m} \\ \text { Head } & =5,5 \mathrm{~kW} \\ \text { Power } & \end{array}$

Freshwater Pump

Seawater Pump

Brand $=$ Taiko

Type $=$ ESC-250D

Capacity $\quad=300 \mathrm{~m}^{3} / \mathrm{h}$

Head $\quad=70 \mathrm{~m}$

Power $\quad=90 \mathrm{~kW}$

Heat Exchanger

Brand = Hisaka

Type $\quad=$ UX-30

Max. Flow Rate $\quad=285 \mathrm{~m}^{3} / \mathrm{h}$

Max. Working Temperature $=180^{\circ} \mathrm{C}$

Max. Working Pressure $=22 \mathrm{Bar}$

Wash Water Treatment

$\begin{array}{ll}\text { Brand } & =\text { Wartsila } \\ \text { Type } & =\text { SWT } 500 \\ \text { Capacity } & =5 \mathrm{~m}^{3} / \mathrm{h} \\ \text { Power } & =6 \mathrm{~kW}\end{array}$

E. Modification of P\&ID Drawing

From the existing $\mathrm{P} \& \mathrm{ID}$, the existing inert gas scrubber system will be modified by changing the openloop system into a closed-loop system. P \& ID drawing can be seen in Figure 4. The modification process causes the need to add components, which are additional processes in the scrubber system. Additions of these components include adding tanks and $\mathrm{NaOH}$ pumps, which function to inject $\mathrm{NaOH}$ into the system. In addition, additional expansion of freshwater tanks is carried out, which is intended to provide additional space for freshwater to expand, as well as providing additional freshwater into the system. In addition, the addition of wash water treatment components is also carried out, which functions to clean wash water so that freshwater can be reused. Then there is a heat exchanger that is used to cool the treated freshwater, which will be used again to clean the exhaust gas. In addition to the addition of components, which are additional processes in the 
system, additional components are also made in the form of fittings in the piping system.

\section{F. Modification of Inert Gas Room Arrangement Drawing}

The drawing of the Inert Gas Room Arrangement modification is done to find out added components due to the modification of the scrubber system. The scrubber system of the inert gas system on the crude oil tanker 85,000 DWT is on the Upper Deck / Main Deck to the boat deck of the ship. The Inert Gas Room itself is on frame 12 to 23 on the ship, precisely on the port side of the funnel. In this modification, additional components such as $\mathrm{NaOH}$ tanks, expansion tanks, wash water treatment, heat exchangers, and pumps were added. The description of the Inert Gas Room Layout modification can be seen in Figure 5.

\section{G. Economic Calculation}

Economic calculation is a cost calculation for modifications made. To carry out economic calculations, it is necessary to know the equipment installed for the modifications made. The equipment installed consists of pumps, pipes, fittings, and other equipment. The following is a list of equipment to be installed in the modification of the freshwater scrubber system.

After finding out the list of required components along with their number and size, then the estimated cost of the equipment is carried out based on the size and specifications of the equipment. Equipment costs are needed to then determine the installation costs for modifications to the freshwater scrubber system.

Capital Expenditure

Capital Expenditure is the cost needed to buy, send, and install the equipment needed for the system modifications made. By using a list of equipment costs that have been obtained, the following is a calculation of

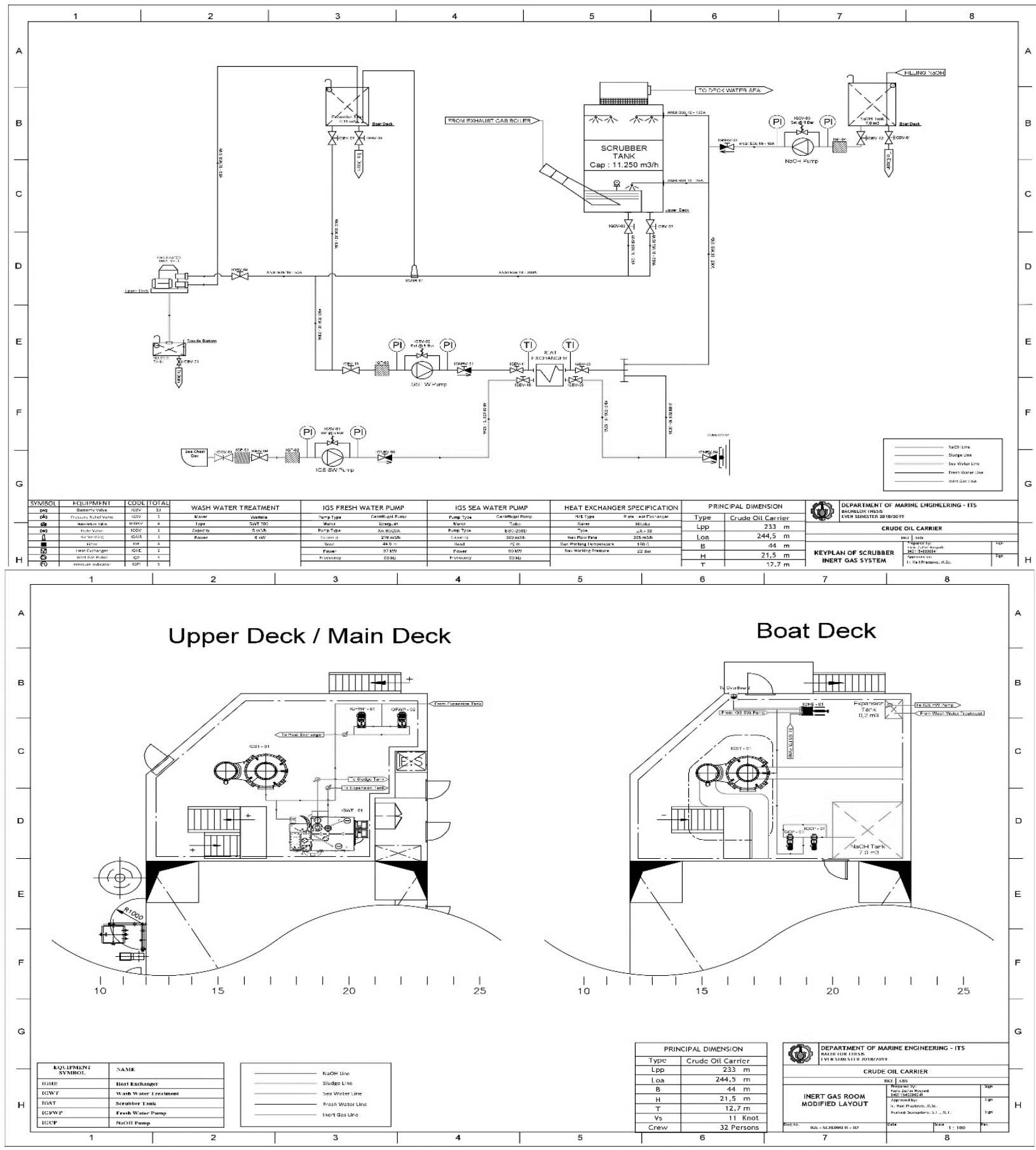

Figure. 5. Inert gas room arrangement of modified system. 
International Journal of Marine Engineering Innovation and Research, Vol. 5(2), Jun. 2020. 59-67 (pISSN: 2541-5972, eISSN: 2548-1479)

the installation costs. Capital Expenditure can be seen in Table 3.

scrubber system requires installation costs of $\mathrm{Rp}$. $1,532,149,820.99$.

TABLE 3.

CAPITAL EXPENDITURE CALCULATION

\begin{tabular}{|c|c|c|c|c|}
\hline No & Item & Estimation & & Total Cost \\
\hline 1 & Equipment Cost & Component + Pipe \& Fittings Cost & $\mathrm{Rp}$ & $946,382,817.00$ \\
\hline 2 & Shipping / Freight Cost & 18.000 USD & $\mathrm{Rp}$ & $254,777,000.00$ \\
\hline 3 & Component Spare Parts & $5 \%$ of Component Cost & $\mathrm{Rp}$ & $34,471,486.88$ \\
\hline 4 & Installation Cost & $5 \%$ of Equipment Cost & $\mathrm{Rp}$ & $47,319,140.83$ \\
\hline 5 & Insurance & $0,5 \%$ of Shipping + Equipment Cost & $\mathrm{Rp}$ & $6,003,299.08$ \\
\hline 6 & Import Duty & $10 \%$ of Equipment + Freight + Insurance & $\mathrm{Rp}$ & $120,666,311.56$ \\
\hline 7 & PPN & $10 \%$ of Equipment Cost & $\mathrm{Rp}$ & $94,638,281.65$ \\
\hline \multirow[t]{2}{*}{8} & PPh Import & $3 \%$ of Equipment Cost & $\mathrm{Rp}$ & $28,391,484.50$ \\
\hline & & Total & $\mathrm{Rp}$ & $1,532,149,820,99$ \\
\hline
\end{tabular}

\section{CONCLUSION}

Based on the results of calculations, designs, and analyzes that have been carried out, conclusions can be taken as follows:

1. A comparison of seawater scrubber systems and freshwater shows that each system has its own advantages and disadvantages. Seawater system has advantages such as easy to obtain with an unlimited amount of water, the seawater has its natural alkalinity, and the installation system is more simple. The disadvantages of this system are seawater is corrosive. Due to its corrosive properties cause the system to use expensive materials, and the maintenance schedule is more frequent. While the freshwater system has advantages that are low corrosive levels, so the system can use cheaper materials, and the maintenance schedule is less frequent. The freshwater system also is better in cleaning exhaust gas and can be operated without disposing of waste into the sea. Disadvantages of this system are that the ship needs to carry additional freshwater and $\mathrm{NaOH}$, The ship needs to install additional components, and the maintenance needs to be done on more component.

2. Modifications to the scrubber system cause the need to add components. The components added to the scrubber system include adding $\mathrm{NaOH}$ tanks, expansion of freshwater tanks, seawater pumps, freshwater pumps, $\mathrm{NaOH}$ pumps, heat exchangers, and wash water treatment units.

3. It modified the Inert Gas Room Arrangement freshwater scrubber system that has been done adjusting to the available space on the ship.

4. The economic calculations that have been done show that the modification of the freshwater
5. From the calculations and drawings of the modifications that have been made show that technically, the modification of the seawater scrubber system into freshwater on an 85,000 DWT Crude Oil Tanker can be done. Economically, the estimated installation cost of a modified freshwater scrubber system costs around 1.5 Bill. Rupiah.

\section{REFERENCES}

[1] Oil Companies International Marine Forum (OCIMF). (2017). Inert Gas Systems: The Use of Inert Gas for The Carriage of Flammable Oil Cargoes.

[2] Safety of Life at Sea (SOLAS). (2004). Ch. II-2 - Construction Fire Protection, Fire Detection, and Fire Extinction.

[3] Biro Klasifikasi Indonesia. (2018). Rules for Machinery Installations Volume III.

[4] Smith, D. (1985). Marine Auxiliary Machinery. Butterworths.

[5] Filancia, A. (2009). Reducing Emissions from Shipping. Sustainable Shipping Conference 2009. San Fransisco: Wartsila's Solutions.

[6] EGCSA. (2010). Exhaust Gas Cleaning Systems Association.

[7] Office of Wastewater Management. (2011). Exhaust Gas Scrubber Washwater Effluent. Washington, DC: United States Environmental Protection Agency.

[8] Maulana, E., Kristanto, W., \& Dahlan, D. (2018). Perencanaan Ulang Wet Scrubber. Seminar Nasional Teknologi, 245-250.

[9] Susilowati, S. E. (2015). ISSN 2338-8102. Inert Gas System on The Motor Vessel Tanker Gandini, 34-40.

[10] Santosa, P. S. (2007). BAHARI Jogja. The Use of Inert Gas System on Tankers, Vol. VII, 38-53.

[11] Chang, R. (2008). General Chemistry: The Essential Concept) Jakarta: Erlangga.

[12] Wartsila Finland. (2017). Wartsila Environmental Product Guide. Vaasa.

[13] The Marine Environment Protection Committee (MEPC).184 (59). (2009). Guidelines for Exhaust Gas Cleaning Systems.

[14] Kern, D. (1983). Process Heat Transfer. Tokyo: McGraw-Hill Book Company Japan, Ltd.

[15] Sularso, \& Tahara, H. (2000). Pumps and Compressor. Jakarta: PT. Pradnya Paramita. 